\title{
Who Benefits from a Bull Market? An Analysis of Employee Stock Option Grants and Stock Prices
}

\author{
Nellie Liang \\ Board of Governors of the Federal Reserve System \\ Scott Weisbenner \\ University of Illinois - Department of Finance
}

First draft: March 2001

This draft: March 2002

\begin{abstract}
Grants of employee stock options have risen dramatically in recent years to both top executives and employees below the senior ranks. This paper examines the growth in stock option grants at S\&P 1500 companies from 1996-1999, and estimates the pay-for-performance sensitivities of the value of new option grants for top executives and, separately, for employees below the top executive levels. We find substantial sensitivities for both sets of employees, but contrary to agency models that would predict lower sensitivities for employees whose actions have less effect on stock price, we find that the sensitivities are larger for employees below the top executive levels. We examine several hypotheses consistent within the agency framework to explain this result, and find that sensitivities for top executives depend on existing stock holdings, and by whether stock prices increase or decrease. We also find that new grants at larger firms are related to industry performance, consistent with more competitive markets for top executive talent to manage large organizations as industry conditions improve. However, some of the higher sensitivity for lower-level employees likely owes to excessive extrapolation of past stock returns, similar to findings of purchases of company stock in 401(k) plans by Benartzi (2001).

JEL Classification: G30, G32, J30, J32

Key Words: employee stock options, pay for performance

The views expressed in this paper are those of the authors and not necessarily those of the Federal Reserve Board. We thank Daniel Covitz, Jean Helwege, Steve Oliner, Jim Poterba, Allen Poteshman, Steve Sharpe, and Michael Weisbach for useful comments, and Robert Paul for exceptional research assistance.

Corresponding author: Nellie Liang

Capital Markets, Federal Reserve Board

$20^{\text {th }}$ and Constitution Ave. NW

Washington, DC 20551

Phone 202-452-2918

Email: nliang@frb.gov
\end{abstract}




\section{Introduction}

Employee stock option grants have grown explosively and have expanded beyond CEOs and other top executives in recent years. Weisbenner (2000) documents that the number of option grants at large public companies grew by 50 percent between 1990 and 1998, and Liang and Sharpe (1999) report that the estimated value of new option grants per employee at large S\&P 500 companies quadrupled between 1994 and 1998. Anecdotal evidence suggests that options have moved down the ranks below executives, with technology companies noted particularly for granting options to employees of all ranks. ${ }^{\square}$ Core and Guay (2001) document that employees not among the top five or so executives received on average about two-thirds of firm option grants in 1994-97, and we document that the share rose to 86 percent in 1999.

A number of studies have investigated determinants of option grants to CEOs (Yermack (1995) and Core and Guay (1999)), and the performance sensitivity of CEO option holdings and stock prices (Hall and Liebman (1998) and Murphy (1999) for a review), but only Core and Guay (2001) have examined the factors that explain option grants to less senior executives and other employees. ${ }^{[}$Additional studies of option grants to employees other than the CEO are important because less senior employees receive the vast majority of the options. Moreover, many of these other employees are not likely to receive restricted stock pay, so the rise in option grants represents a significant change in their compensation. In addition, mid-level employees likely have much less firm-related stock wealth relative to CEOs who are required to hold a substantial

\footnotetext{
${ }^{1}$ For example, one survey indicated that only 15 percent of large corporations restricted employee stock option grants to upper management; 75 percent of the firms granted options to upper and middle management, and 10 percent granted options to all employees (Institutional Investor, Oct. 1999). A survey by Inc. showed that 39 percent of the fastest growing privately-held companies gave options to all full-time employees in 1999 (Inc., Oct. 1999).
} 
amount of shares, such as stock ownership at least four times base salary (Core and Larcker, 2000).

This paper examines the dramatic growth in stock option grants at large U.S. companies between 1996 and 1999, and estimates the sensitivities of option grants to firm stock prices for top executives (identified in company proxy statements) and, separately, grants for other employees ("middle management"). Our approach follows the pay-for-performance literature that uses a fixed-effects framework to focus specifically on how firms adjust compensation in response to changes in firm value. It expands the research by contrasting pay-for-performance elasticities of option grants for CEOs and top executives to those for middle management. Assuming that the top executives have a greater effect on firm value and they are less risk averse, agency theory would predict that top executives would have greater pay-performance elasticities.

Annual stock option grants, like cash salaries and bonuses, are used to reward employees for past performance, leading to a positive relationship between the value of new option grants and firms' stock prices. ${ }^{\mathrm{B}}$ The timing of option grants supports this framework, as new grants tend to be made around or immediately following annual performance assessments. Specifically, we find that, based on grants to the top executives from 1995 to 1999, more than one-half of firms grant options only once a year, and more than 80 percent grant options once or twice a year. The greatest concentration of options are granted in January, followed closely by February and December, and these three months account for about 50 percent of total options granted each

\footnotetext{
${ }^{2}$ See also Matsanuga (1995) for a study of firm-wide option grants.

${ }^{3}$ The focus on how performance affects option grants is different from, but related to, questions of whether options result in superior performance - that is, whether increased ownership stakes of employees raise firm value by eliciting more effort and reducing the consumption of perquisites. We address this question further in Section IV.F.
} 
year.

Options differ from cash and salary because they have vesting restrictions that could work to retain employees. ${ }^{\mathrm{B}}$ Thus, option grants could increase, and perhaps substitute for salary and bonus, following stock price increases because firms use options to retain employees, where firm price is a signal of managerial success. Oyer (2000) shows that it may be optimal to tie compensation directly to firm value, assuming that compensation contracts are costly to renegotiate and outside opportunities are correlated with firm performance. Fee and Hadlock (2001) find that the probability of obtaining a CEO position at a new firm is strongly related to the stock price performance of the firm at which the employee was previously employed. Options also have the desirable feature that their value increases with future increases in the stock price, which reflects in part worker skill and effort, thus encouraging continued high performance.

Our analysis documents a positive and significant pay-for-performance sensitivity for option grants to CEOs, and for all top executives, similar to that found in Hall (1998). For middle management, we also find positive and significant pay-for-performance sensitivities, but they are greater than those for top executives. This finding is in contrast to predictions of standard principal-agent models that pay-for-performance sensitivities for middle management should be lower than those for top executives because their actions have less effect on firm value and, because of less wealth, greater risk aversion. Moreover, stock prices are a less informative signal of middle management than top executive effort. The paper then explores several plausible reasons for why option grants to middle management could be more sensitive to firm

\footnotetext{
${ }^{4}$ These figures are for firms with fiscal years ending in December.

${ }^{5}$ It is unclear whether options in fact reduce turnover. If options help firms attract less risk averse employees, then it
} 
performance than grants to top executives. In particular, we explore whether greater share and option ownership of top executives, the asymmetric effect of price changes on incentives provided by options, and differences in participation constraints can account for the higher price sensitivity of top executives. While these factors help to explain some of the difference, we argue that some of the difference owes to the greater willingness to accept options, or greater demand for options by middle management when firm prices have been rising. This behavior could arise if employees extrapolate recent favorable returns to the future, similar to greater purchases of company stock in $401(\mathrm{k})$ plans when stock price returns have been high, as documented by Benartzi (2001). Grinblatt, et al (1995) also find that mutual fund managers buy stocks based on past returns.

Section II outlines how standard principal-agent models guide our predictions. Section III of the paper describes our data and documents the growth of option grants to middle management employees. Our empirical tests of pay for performance sensitivities are reported in Section IV. Robustness checks, including estimation of the effect free cash flow has on option grants, are conducted in Section V. Section VI concludes.

\section{Pay for Performance Framework and Tests}

An extension of the standard principal-agent model can help make more precise what theory predicts for rewards for performance, and differences in the sensitivity of rewards for top and middle management. The standard model considers the problem of how risk-neutral shareholders try to induce risk-averse managers whose actions are not observable to maximize firm performance. The value of the firm $\mathrm{V}$ increases in firm actions $\mathrm{A}, \mathrm{V}(\mathrm{t})=\mathrm{A}+[\mathrm{V}(\mathrm{t}-1)]+\varepsilon$, 
where $\varepsilon$ is normally distributed noise. Managers are risk averse and have a disutility for effort. Holmstrom and Milgrom (1987) calculate the optimal incentive scheme, yielding the familiar result that the optimal compensation scheme depends on actions and random noise:

$$
\text { Compensation }=\alpha+\beta(\mathrm{A})+\varepsilon
$$

and

$$
\beta=1 /\left(1+2 \rho^{*} \sigma^{2}\right)
$$

where $\rho$ is a measure of (absolute) risk aversion, and $\sigma^{2}$ is the variance of firm value. When output is certain, $\sigma^{2}=0$, or managers are risk-neutral, $\rho=0$, then $\beta=1$. More realistically, $\beta$ will be less than 1, and will be lower for more risk-averse managers and for firms with greater variance in value. Garen (1994) finds that the more variable a firm's fortunes, the less the sensitivity of pay for performance.

An extension of this model is to allow different actions to have different effects on firm value (Baker and Hall, 1998). That is, $\mathrm{V}(\mathrm{t})=\gamma \mathrm{A}+\mathrm{V}(\mathrm{t}-1)+\varepsilon$, where $\gamma$ could vary. They show that the $\beta$ coefficient in the optimal incentive scheme is then:

$$
\beta=\gamma 2 /\left[\gamma 2+2 \rho^{*} \sigma^{2}\right]
$$

Baker and Hall focus on whether the action has a constant dollar effect on firm value or a percentage effect on firm value, ie., whether the manager wants to buy a corporate jet that costs the firm \$x, or the manager changes firm strategy that costs or adds value of y percent. We use the intuition of their model to focus on differences in $\gamma$ arising from the marginal product of effort of top executives and middle management. In particular, we assume that the marginal product of effort of top executives is greater than for middle management, leading to a larger pay-for-performance sensitivity. In addition, assuming that risk aversion declines as wealth 
increases, top executives are less risk averse than middle management leading to the prediction that $\beta$ should be greater for top executives.

Within this framework, a commonly used empirical specification estimates the flow of CEO pay (C) using the following structure:

$\Delta \ln (\mathrm{C})=\mathrm{b}^{*} \Delta \ln ($ performance $)+$ firm effects + time effects $+\mathrm{c}^{*} \mathrm{X}+\mathrm{e}$, where $b$ is the pay-performance elasticity. Performance is often measured by firm value (Murphy, 1986 and Murphy, 1998 for a survey). As noted in Bertrand and Mullainathan (2001), returns are a flow measure, and in practice, given firm fixed effects, market value or equivalently, stock price if shares outstanding are constant, is the appropriate measure of performance.

To motivate performance, Holmstrom (1979) indicates that the choice of performance measures should be a function of the informativeness of the workers' action choices. Heneman et al. (1999) argue that very concrete measures, such as absenteeism, safety inspection ratings, have greater motivational value for workers at lower organizational levels than broad measures of financial performance, such as profits or stock price.

\section{Data Sources and Trends in Employee Stock Option Grants}

Our data on employee stock option grants come primarily from Execucomp, which provides compensation data for top executives, as defined on the company's proxy statement, of S\&P 1500 firms. While the data on option grants to top executives is explicit, we derive the grants to other employees through a variable that gives the percentage of the total option package that is granted to each executive. This variable allows us to estimate option grants to all 
employees in the years when top executives receive options. ${ }^{6}$ We supplemented these data with data from the company's 10-K statements to fill in option grants to other employees when executives did not receive any.

Our sample starts with 7,517 firm-level observations of cash salary to executives in 1996 to 1999. We eliminated 830 observations because of missing data for the number of employees or shares outstanding, or data errors in Execucomp. For example, options may have been granted under a plan for the subsidiary of the parent, and the percentage of options granted is based on the subsidiary's options, which can lead to more than 100 percent of the parent's total options granted to top executives. Another 628 observations were dropped because there were not sufficient data to calculate Black-Scholes option values (we required at least 2 years of monthly returns on CRSP to calculate the volatility of stock returns). This leaves 6059 observations to construct the summary statistics displayed in table 1 .

Our data confirm that grants of employee stock options rose considerably in the late 1990s. For all S\&P 1500 companies in our sample, the number of option grants rose from 1.41 percent of shares outstanding in 1996 to 1.83 percent in 1999 (table 1, top panel). The increase has been pronounced at both large (S\&P 500) and small (S\&P mid- and small-cap) firms. In addition, small firms grant considerably more options than large firms, and technology firms grant more than non-tech firms. To the extent smaller firms and more technology-oriented firms are those with greater growth prospects and asymmetric information between management and outside investors, stock-based compensation can serve to reduce agency costs.

\footnotetext{
${ }^{6}$ We checked all the observations in Execucomp where executives were recorded as receiving less than 1 percent of firm-wide option grants, or if firm-wide option grants exceeded 20 percent of shares outstanding. To test the accuracy of the Execucomp data, we compared these data to data on options collected from 10-Ks for S\&P 500 firms from 1996-99. The correlation between firm-wide option grants, based on our revised Execucomp data, and firm-
} 
Option grants for top executives and for the CEO individually were roughly stable during 1996-99, indicating that the growth in option grants during this period was skewed to other employees. Option grants-to-shares outstanding to these employees rose from 1.18 percent in 1996 to 1.58 percent in 1999 , while grants to executives have fluctuated between 0.23 and 0.26 percent. A substantial share of employee stock options is granted to top executives each year. In 1996 and 1997, about 17 percent of the total value of options granted by the S\&P 1500 firms went to the top executives; this share edged down to 14 percent in $1999 .^{\text {⿴囗 }}$

The measurement of option values is the subject of a number of recent papers that incorporate risk aversion of non-diversified executives (Muelbroek, 2000; Hall and Murphy, 2000). In this paper, we simply estimate the Black-Scholes value, adjusted for dividends, as if the options were negotiable and executives were risk-neutral. The risk-free rate is approximated by the 5-year Treasury note yield at the time of the grant. Dividend yield and stock price volatility are from CRSP. We assumed that all options were granted at-the-money and are exercised after five years, consistent with the exercise patterns in Huddart and Lang (1996), Carpenter (1998), and Weisbenner (2000).$^{8}$ We discuss below how a measure of the value of options that could be affected by changes in wealth and risk aversion affects the interpretation of our main results (see Section IV.D).

For all employees, the Black-Scholes value of option grants rose from about \$1,058 in

wide option grants from the 10-Ks was .95 .

${ }^{7}$ The unweighted average of the fraction of options granted to the top executive across S\&P 1500 firms was 27 percent each year from 1996-99, a bit lower than the 33 percent during 1994-97 reported by Core and Guay (2001), but the difference is probably due to the decline in the fraction of grants to top executives over time, and that our sample includes more recent years.

${ }^{8}$ Assuming instead an option life of 10 years would increase the level of grant values (by 34 percent in 1999 for S\&P 1500), but does not change the regression results. 
1996 to $\$ 2,508$ in 1999 (table 1, bottom panel). ${ }^{\square}$ The grant value per employee is normalized by the total number of employees of the firm, not just those who receive options (this number is not available to us). Despite lower grant rates, option values at large firms were greater than at small firms, because larger firms tend to have higher stock prices and option values. For middle management employees (all employees less the top executives), the Black Scholes values rose from $\$ 879$ in 1996 to $\$ 2,159$ in 1999 . Top executives have seen substantial rises as well, reaching $\$ 1,167,200$ per executive in 1999 , about one and a half times their annual cash salary and bonus. For top executives, the share of total compensation from options has increased also, from 43 percent in 1996 to 62 percent in 1999.

Data on cash compensation for middle management employees are not available for most firms. Aggregate data, however, suggest that the increase in option grants has been substantial relative to cash compensation. For example, based on an average salary of $\$ 37,700$ in 1996 that has grown by about 3.5 percent per annum in recent years, the share of compensation from option grants has doubled, and in 1999, represented 5.7 percent of cash plus option compensation. This rise in option grant values has implications for measures of aggregate wage growth. For example, the Bureau of Labor Statistics' Employment Cost Index, which does not include stock options, grew on average about 3.5 percent each year from 1996 to 1999 . An estimate of growth including stock options would have boosted wage growth on average by 0.4 percent over this period, and 0.6 percent in 1999 .

\footnotetext{
9 Another indicator of their growth is that the Black-Scholes value of option grants after-tax rose from 5.3 percent of firm net income in 1996 to 10.2 percent in 1999 for the S\&P 1500.

${ }^{10}$ Figures for compensation are from the National Income and Product Accounts, Tables 6.2 and 6.5.
} 


\section{Empirical Tests and Results}

To examine how current performance relates to the value of future option grants, we regress stock option grant values on company stock prices in a fixed-effects framework. The framework allows us to identify the relationship between prices, which vary substantially over time, and subsequent option grants, while controlling for firm-specific factors that do not vary as much over time. The fixed-effects specification controls for factors, such as corporate governance, firm-wide attitude towards risk, long-run investment opportunities and other slowly changing firm-specific characteristics, that likely muddy the interpretation of the coefficient on price/return in a cross-sectional analysis. Our measure of option grants is the Black-Scholes value of option grants per employee in a given year, as in Hall (1998) for CEOs. We do not use the option delta as an incentive measure, as in Core and Guay, since top executives and other employees in the same firm would face the same delta.

From the 6,059 observations, we dropped 61 observations that did not have a lagged stock price and 164 observations (50 firms) that never granted options during this period. Since we use a log-log specification, we lose an additional 157 zero-grant observations from firms that granted options at least one year from 1996-99. Our final sample contains 5,677 observations, representing 1,865 distinct firms. To address mergers, spin-offs, and other reorganizations in our fixed-effects specification, for those observations that involved a substantial annual change in the number of employees ( $25 \%$ or more), we split the company observations into a 'pre-merger' entity and a 'post-merger' entity, which included the firm observations in the year of the change. Of the 5,677 observations with firm-wide grants greater than zero, there are 30 observations in which a firm did not grant any options to middle management that year, and 549 observations in 
which none of the top executives received options that year.

\section{A. Stock Option Grant Values and Firm Stock Price}

Table 2 presents estimated coefficients of regressions of the value of stock option grants per employee in year $t$ on firm stock prices at the end of year $t-1$ (both variables in logs). Firm stock price represents the accumulation of past returns; Hall shows that returns up to 3 years earlier are significant for CEO option grants, while Core and Guay show that only the contemporaneous return is significant for non-executive option grants.

The log specification allows us to estimate the elasticity of grant value with respect to firm value. Absent changes in volatility, dividend yield, and the risk-free rate, an elasticity of zero indicates firms grant the same value of options each year, while, assuming options are granted at-the-money, an elasticity of one indicates firms grant the same number of options each year. In the latter case, the value of option grants will fluctuate on a one-for-one basis with firm value.

There are, of course, determinants of stock option grants other than stock price that might not be reflected adequately in our parsimonious fixed-effects specification. In Section IV.E, we show that the sensitivity of option grants to firm stock price is not altered by the inclusion of other variables such as option exercises, free cash flow, and the market-to-book ratio.

For top executive option grants, the estimated coefficient on stock price is 0.29 . This elasticity is similar to Hall (1998) who finds that option grant values to CEOs increase with lagged stock price returns, and conforms to anecdotal evidence that roughly one-third to 40 percent of firms may have CEO option plans that involve a fixed number of options each year 
(see Hall, 1998).

For comparison, the fourth column of table 2 shows that the estimated pay for performance sensitivity of cash-based compensation for top executives is essentially zero, also similar to Hall (1998) and Hall and Liebman (1998), but somewhat smaller. In particular - Hall and Liebman (1998) find a coefficient of .06 on lagged return - but their sample encompasses 1980-94, a much earlier time period, when option grants were less prevalent. ${ }^{12}$ Indeed, the last column in table 2 shows the pay for performance sensitivity of cash-based compensation was 0.07 over the period 1992-95. Some of this difference in responsiveness of different forms of compensation for top executives to firm performance may owe to the loss of tax deductibility for cash compensation in excess of $\$ 1$ million to any executive. These results suggest that the growth in the use of stock options has substantially lessened the extent to which cash salary and bonuses are used to reward top executives for good past performance. The increased reliance on options as a reward for past performance may owe to the vesting restrictions and provision of incentives for good performance, as well as the accounting benefits.

For middle management, the estimated coefficient on lagged firm stock price is 0.53 , suggesting a higher pay-for-performance relationship for middle management than top executives. This finding is counter to theoretical predictions of agency cost-based models that the performance relationship should be stronger for top executives than middle management because their actions have a larger effect on firm value and they are less risk averse. Below we examine a number of hypothesis that could help explain this result and still be consistent with

\footnotetext{
${ }^{11}$ Similar to Hall, we find that roughly 30 percent of firms grant the same number of options to the CEO in two consecutive years (fixed option plan); however, half of this reflected no option grants to the CEO during either year.

${ }^{12}$ Hall \& Liebman provide a good summary of past research on the pay-for-performance sensitivity of CEO cash compensation. They conclude that past research typically finds that the elasticity of CEO cash compensation to firm
} 
extensions of the simply agency model.

The coefficient on grants to all employees is also of interest because it allows us to assess the importance of stock price gains on new option grants in recent years. For grants to all employees, the coefficient of 0.45 suggests that a 10 percent increase in a firm's stock price leads to a 4.5 percent increase in grant value per employee. ${ }^{-1.3}$ These results imply that firms increase the value of new option grants following strong performance, to reward and help retain employees, and to attract new employees. Employees, however, do not receive the full effect of the rise in firm value, since firms reduce the number of grants as stock prices rise. Otherwise, a rise in stock price would lead to an equivalent rise in the value of the options granted, and a coefficient estimate of 1 . The coefficients on the time series dummies indicate that stock option grant values per employee have increased 36 percent from 1996 to 1999, independent of changes in stock price.

To interpret these coefficients, we attempt to parse out the increase in stock option grant values in the late 1990s due to rising stock prices. From 1996 to 1999, stock option grants per employee were estimated to increase from about $\$ 1,050$ to $\$ 2,500$ at S\&P 1500 firms. To estimate the fraction of this increase attributable to stock price changes over this period, we applied the estimated elasticity of 0.45 to the actual change in stock price observed to calculate the expected change in option grant value for each firm in the sample. This method implies that changing stock prices over 1996-99 increased grant value per employee by $\$ 990$, or about twothirds of the total increase observed over the period. Another $\$ 380$ of the increase in grant values

value, over the 1980s and early 1990s, is around .10 .

${ }^{13} \mathrm{~A}$ robust regression and median regression yield very similar point estimates. The coefficient estimate for $\log$ price is .41 (standard error of .02) in the robust regression and .43 (standard error of .03) in the median regression. 
per employee can be attributed to the time trend, which could less risk aversion by employees.

\section{B. Why is there a stronger performance relationship for middle management?}

The higher coefficient estimates on lagged firm stock price for middle management than top executives is puzzling within the agency framework. We explore several alternative factors in this section.

\section{(i) Existing ownership.}

One mitigating factor is that options have been part of top executive compensation packages for a long time, whereas they are a relatively new phenomenon for other employees. Relatedly, top executives are more likely to receive restricted stock grants than other employees, and thus already have a large ownership share and more options outstanding. Our data indicate that the average (median) value of stock and options held by top executives in 1998 was $\$ 51$ million (\$3 million). These other forms of equity ownership held mostly by top executives could reduce an estimated pay for performance sensitivity because option grants are only one of several ways by which to tie pay to performance. In contrast, using data from the 1998 Survey of Consumer Finances, we estimate that the average own company stock holdings (outside of retirement plans) was $\$ 18,000$ per household employed by publicly-traded corporations. ${ }^{15}$ The $\$ 18,000$ represents about 6-1/2 percent of the average net worth across households, suggesting that direct ownership of company stock is not a major share of wealth. Another mitigating factor could be that the actual executives that comprise "top executives" could vary over time, an issue

\footnotetext{
${ }^{14}$ New firms entering the S\&P 1500 over the sample increased grant values by an additional $\$ 130$ per employee.

${ }^{15}$ The 1998 Survey of Consumer Finances is a stratified sample of U.S. households with wealth less than the Forbes 400 wealthiest Americans. The survey data show that the average direct holdings of own company stock was $\$ 6,000$ per household. Since roughly 33 percent of all workers are employed by a publicly-traded corporations, this would
} 
we address below in Section IV.A.

To examine whether existing ownership share in the company affects the relationship between firm performance and future grants, we split the sample by the top executives' collective ownership share over 1997-98 (the middle two years of our sample). The top quartile of ownership share includes firms for which each top executive held more than 1-1/4 percent of the firm on average, and the bottom quartile are those for which each top executive held less than 0.15 percent of the firm on average. The ownership share variable represents what fraction of a dollar increase in firm value goes to the executive. We interact the firm stock price variable with the quartile indicator variables (combining the middle two quartiles) and then regress option grants per employee on these variables.

As shown in the top panel of table 3 , for top executive option grants, we find that for firms in the bottom quartile of ownership share, the coefficient on lagged stock price is significant, and the estimate of 0.41 is greater than the coefficient of 0.29 for the whole sample. For firms in the top quartile of ownership share, the coefficient is only 0.06 and insignificant. The difference between .41 and .06 is significant at the 1 percent level. Thus, our results suggest strongly that option grants to top executives are tied more closely to firm performance when executives have less of their wealth already tied to the performance of the firm. However, coefficient estimates for top executives that have low ownership are still lower than those for middle management in the same firm. ${ }^{16}$ Thus, accounting for existing ownership of top executives does not explain the entire differential in pay-for-performance elasticities of top

imply an average holding of own company stock of $\$ 18,000$ per household employed by a publicly-traded company.

${ }^{16}$ We also divided the sample by dollar value of ownership stake and obtained qualitatively similar, though less striking, results. Firms whose value of executive stock holdings was in the bottom quartile had a price elasticity of .37 (standard error of .09) compared with .25 (standard error of .06) for firms in the top three quartiles. 
executives and middle management.

\section{(ii) Asymmetric incentive effects from options.}

Another factor that could account for the lower pay-for-performance sensitivity of top executives relative to middle management is that when firm performance is poor, and options are out-of-the-money, outside shareholders may want to restructure compensation, particularly for top executives because of the greater effect of their actions on firm value. Out-of-the-money options can induce greater risk-taking, or make executives less inclined to put in effort if the likelihood of raising price above the strike price is low. Firms may then want to grant new atthe-money options or lower the exercise price of (reprice) their out-of-the-money options to mitigate these incentives. Because middle management actions likely have less effect on firm value, principals may be less concerned with incentives to take greater risk or apply less effort.

To test whether the lower pay-for-performance sensitivity for top executives is due to different sensitivities by whether firm prices have risen or fallen, we split the sample into quartiles based on average annual stock price returns from 1996 to 1999 , and interact the quartiles indicator with firm lagged stock price. The results are displayed in the bottom panel of

table 3. The bottom quartile of firms had an average stock return of less than 6.9 percent per year (just under 20 percent of all firms had an average negative return), while the top quartile had an average stock return of more than 42.7 percent per year. The average annual return for the S\&P 1500 during this period was 24 percent.

The estimated pay for performance sensitivity for firms that had the lowest stock price gains is 0.04 for top executives, suggesting that when stock price performance is poor, option grant values do not change, as firms fully offset the decline in price by increasing the number of 
grants to executives (bottom panel, table 3). The estimated sensitivity for the best performing firms is substantially greater, 0.46 , statistically different from the estimate for the worst performing firms. These results suggest that firms offset price declines by granting more options to top executives to mitigate adverse incentives when options are deeply underwater. In contrast, estimated elasticities for middle management do not differ significantly by whether firm stock prices have risen or fallen, consistent with our framework that actions of top executives have more effect on firm value and firms adjust compensation to avoid excessive risk-taking. Again, however, the pay-performance elasticities for top executives for the sample of firms with the highest returns exceeds the pay-performance elasticities for middle management of the same firms. These results suggest that the asymmetric effect of price changes on incentives arising from options can help to explain some of the differential in pay-performance elasticities between top executives and middle management, but it does not explain the entire difference.

\section{(iii). Relative value and new economy}

Oyer (2000) shows that options which reward industry performance, i.e. "luck," might be optimal when turnover and adjusting terms of employment contracts are costly, and outside opportunities are correlated with firms stock price. If turnover costs are more costly for top executives than middle management, then top executive elasticities should be greater. On the other hand, in new economy firms (Rajan and Zingales, 2001), middle management may be a relatively greater source of value. When we contrast results for tech and non-tech firms, where tech represents new economy, we still find the same differential in the pay-performance sensitivities between middle management and top executives. 


\section{(iv). Industry performance and participation constraints}

Another possible reason for a different performance relationship for middle management than top executives relates to relative demand as labor markets tighten, which increases particularly for top management with the skills to manage large organizations. The motive to grant options when labor markets are tight may be greater when the industry as a whole is performing well, since firms in the same industry are likely to be the closest competitors for skilled labor. Thus, strong industry performance may proxy for more competitive labor markets (Himmelberg and Hubbard, 2000), and firms may need to grant more options to retain top executives and important employees when labor demand is high. Moreover, options may be a desirable means of compensation to meet market pressures since vesting and forfeiture restrictions help to tie an employee to the company.

To measure industry performance, we calculate stock price indexes for fourteen industry categories based on grouping 2-digit SIC categories. The price index for each industry is based on calculating annual firm returns, and weighting the firm returns by beginning-of-period market value. As shown in table 4, there have been substantial differences in performance across industries in recent years: Firms in the mining, construction, and utility sectors recorded losses or small gains on net since 1995 , while the computer-related technology sector more than quadrupled, and the telecomm, medical-related technology, retail/wholesale trade, and financial sectors more than doubled in value. Demand for senior executives in these sectors might be particularly intense. Between 1997 and 1999, there is also substantial variation, with 6 of the 14 sectors registering losses.

When we add beginning-of-period industry price to the regression of option grant values 
on firm price, the estimated coefficient is positive and significant for top executives, and positive and marginally significant for middle management (table 5). For top executives, the estimated coefficient on industry price is large, 0.43 , and larger than that on firm price. In contrast, for middle management, the coefficient on industry price is about half the size of firm price, suggesting that own firm performance is a more important determinant of option grants. Note that the coefficient on firm price in each of the regressions is basically unchanged, suggesting that industry price provides different information. Since we control for industry performance in these regressions, the coefficient on own price represents how option grants are related to firm performance relative to the industry. These results suggest that industry returns could approximate more competitive markets for top executives, consistent with the standard CEO compensation framework that allows for the value of CEO talent to rise with the scale of operations.

To further explore the hypothesis of more competitive markets for executive talent in periods of rising industry prices, we split our sample into quartiles based on asset size, similar to the test constructed by Himmelberg and Hubbard for CEO pay. A finding that the coefficient on industry price increases with asset size would be consistent with this hypothesis. As shown, coefficients on industry price rise significantly with firm asset size for option grants to top executives (table 5, bottom panel). For top executives at the smallest firms, there appears to be little sensitivity to industry performance, but top executives at firms in the top three size quartiles have large coefficients on industry price. For middle management, the coefficient on industry price also increases with firm size, although smaller in magnitude, suggesting that the market for executives with skills to manage large organizations may exert pressures on large firms to 
increase option grants to their management just below the very top ranks when labor markets are tight.

Table 6 presents the results from an alternative regression specification in which the firm stock price is interacted with stock returns and executive ownership, and industry price is interacted with firm size simultaneously. As seen by comparing table 6 with the results in tables 3 and 5 , the use of all the interaction terms at once does not alter the results or their significance. These regressions explain between $9.2 \%$ and $13.6 \%$ of the within-firm variation in option grant value.

In another specification, we replace the dependent variable of value of stock option grants with the number of stock options granted. We find that the estimated coefficients on lagged firm stock price are negative, as expected, and that as prices rise, the number of grants to top executives fall by more than grants to middle management, consistent with the lower grant value elasticities (table 7, top panel). In addition, the coefficients on industry price remain positive and significant for top executives (table 7, bottom panel), which is also consistent with the option grant value regressions.

\section{(v) Behavioral explanations.}

We have evaluated a number of potential factors that could help to explain why the performance sensitivity of middle management is greater than for top executives, and why results could still be consistent with agency theory. However, while most of the hypothesized factors account for some of the difference in the coefficients, the basic counter-intuitive result remains. Thus, we argue that some of the effect owes to middle management's tendency to extrapolate

\footnotetext{
${ }^{17}$ Carter and Lynch (2001) show that most repricings are in the high-tech sector, which they argue is consistent with using repricing to retain executives in competitive markets.
} 
previous high returns to the future. That is, when returns have been high in the past, they demand "a piece of the expanding pie," and thus are willing to accept, and even demand, compensation in the form of options. Such behavior has been documented in Benartzi (2001) who finds that employees purchase more company stock if previous stock returns were higher. Similarly, Lambert and Larcker (2001) surveyed 122 managers and executives, and found that employees overestimated the value of their options, by between 50 and 200 percent. Those who had exercised options during the past year and had higher expectations for future stock price performance placed higher value on their stock options. In addition, younger employees in low managerial positions had the most upward bias in perceived values. Evidence on stock purchases more generally suggest investors respond to past returns: Grinblatt, et al (1995) document that mutual fund managers buy stock based on past returns, and Sirri and Tufano (1998) shows that net investment in mutual funds increases if the funds had high past returns. Even in the aggregate, evidence from surveys of stock investors shows that realized returns in the past twelve months are a significant predictor of returns expected in the next twelve months, suggesting that investors may project forward past growth rates.

These results also suggest that employees may have a different perception of the stock price distribution for employer stock than the markets', consistent with familiarity or excessive extrapolation. Huberman (2001) shows that investors have a strong tendency to invest in stocks that they are familiar with. Surveys of investors also show that investors believe that own company stock is a less risky investment than a diversified portfolio of stocks, and in turn less than another individual stock (see Vanguard, 2001, and John Hancock, 1999).

\footnotetext{
${ }^{18}$ See the PaineWebber Index of Investor Optimism, a monthly survey conducted by The Gallup Organization.
} 
Thus, there appears to be a growing amount of evidence that investors use past returns as an indicator of future returns and that investors view stocks they are familiar with as less risky. This type of behavior is consistent with a higher pay-performance elasticity for middle management than top executives, because middle management may desire stock-based compensation following a rise in firm value so as to "capture a piece of an expanding pie." Large gains realized from exercising previously-granted options could affect how employees value new grants. It is possible, however, that this extrapolation of past returns to future performance could be rational if employees believe options improved worker productivity and provided mutual monitoring in the workplace, which caused the stock price gains. But this explanation does not help to explain the greater pay-for-performance elasticity for middle management versus top executives when middle management efforts are tied less explicitly to stock prices.

\section{Robustness Checks and Extensions}

In this section we consider alternative explanations for the link between firm value and option grants. In addition to the robustness checks, at the end of the section we also provide estimates of the effect financial constraints have on the use of stock options, as well as preliminary evidence on the stock price response to option grants.

\section{A. Tenure of Executives}

A possible reason for the smaller estimated coefficients on firm price for top executives is that we were not holding constant the executives (the individuals comprising "top executives" could change over time). If changes in total option grants for top five executives were reflecting 
turnover among executives rather than changes in firm performance, then the estimated coefficient on price would be biased downward. We explore this possibility by tallying the average number of times an executive is recorded in the proxy statement, and comparing this with the number of years the firm is in the sample. As shown in table 8 , for firms in the sample for 3 years, the average (median) number of times an executive is included is 2.5 (3) years, and two-thirds of the executives are included in all three years. Even among the firms in the sample for the entire four-year period, one-half of the executives were with the firm the entire period.

Table 9 presents regression estimates when only firms with low executive turnover are included. To be considered a firm with low executive turnover, each executive had to be included in the proxy statement twice if the firm is in the sample two or three years, and at least three times if the firm is in the sample four years. These criteria yield a small sample of 1,359 observations, out of 5,128 used in previous estimations. Nonetheless, we find very similar, though slightly higher, coefficients on firm price and industry price for top executives. The coefficient on firm price for top executives remains smaller than that for middle management; and the coefficient on firm price for top executives remains smaller than that on industry price. Thus, we conclude that more rapid turnover among the top executives is not the primary reason for the smaller estimated coefficient on firm stock price in the top executive regressions.

\section{B. Stock Option Exercises}

An additional variable that correlates with stock prices is the amount of employee stock options exercised. If firms have a target amount of options they wish employees to hold, then firms might increase the value of option grants following periods in which option exercises were high in order to replenish outstandings. Option exercises tend to rise with recent stock price 
performance (Huddart and Lang, 1996, and Core and Guay, 2001), so our pay-for-performance sensitivities might be biased when option exercises are not included. To address this issue, we include stock option exercises in the regressions. Because the collection of option exercise data is so time-intensive, we have limited our sample to firms in the S\&P 500.

As shown in table 10, option exercises as a percent of shares outstanding for S\&P 500 firms have risen steadily since 1996 from 1.0 percent to 1.3 percent in 1999. Gains from exercising stock options are estimated as the difference between the year-end stock price to the average strike price of options exercised, as reported on the firms' 10-K statements, multiplied by the number of options exercised. These gains soared from 1996 to 1999 , roughly tripling to about $\$ 4,800$ per employee in 1999 . Thus, we run a regression of grant value per employee including exercise gains as an explanatory variable (table 11). We estimate a both a log and linear specification. Consistent with a target option share, the coefficients on option exercise gains are positive, but the estimated effects are fairly small. For example, the linear regression suggests that firms increase the value of stock option grants by $\$ .07$ for every $\$ 1$ of gains realized from option exercises during the year. Importantly, the coefficient on firm price is not materially altered by the addition of the exercise variable.

\section{Broader Base of Option Recipients}

A final source of estimation error we address is that the rise in grant value per employee attributable to the rise in stock price is not because firms are rewarding employees with more options because of better performance, but that options are being awarded to more employees.

\footnotetext{
${ }^{19}$ The coefficient on log price in the linear specification is not directly comparable to the coefficients from the $\log$ regressions presented in the earlier section. However, the implied elasticity of option grant value with respect to stock price from the linear regression (evaluated at the sample means) is .42, very similar to the .45 elasticity estimated directly in table 2 .
} 
That is, perhaps the price coefficient is reflecting that option programs are becoming more broadbased in response to rising stock prices, rather than a specific individual receiving more options. Recall, the grant value per employee variable is normalized by the number of employees of the firm, not just those who receive options. Unfortunately, we do not have data on how many employees receive options, so we use a crude proxy for firms in which options have become more broad-based. Data from Execucomp suggest that the fraction of options granted to top executives has fallen modestly in recent years, with the decrease concentrated in non-technology firms. The fraction of grants to top executives fell from .20 to .16 from 1996 to 1999 in nontechnology firms, while it was essentially unchanged for technology firms (.12 in 1996 and .11 in 1999).

Thus, to test whether a change in option coverage can explain the coefficient on lagged stock price, we break the sample into technology and non-technology firms. If option programs are becoming more broad-based over time in response to stock price increases, we would expect a higher price coefficient in the non-technology sample. When we estimate our basic specification for grant values, the coefficient on lagged firm stock price is essentially identical for technology and non-technology firms (Table 12).

\section{Alternative measures of option grant values}

Following other empirical work in this area, we rely on Black-Scholes estimates to measure the value of employee stock option grants. But Hall and Murphy (2000) and Muelbrook (2000) show that option values can depart from Black-Scholes estimates, and depend on employee risk aversion, wealth, and diversification. Abstracting from effort-inducing benefits of options, employees with high risk aversion and little diversification would value options at less 
than their Black-Scholes value, while those with little risk aversion and substantial

diversification might place greater value on options. Thus, stock prices could affect the

difference between the Black-Scholes estimates and the value perceived by employees because

changes in prices can affect wealth, diversification, and even risk aversion. It is plausible that

top executives value options less than middle management as firm stock prices rise, because

wealth related to the firm increases, leading likely to less diversification and higher risk aversion.

Incorporating these factors could help to explain why companies reduce the number of options as prices rise, and increase the number of options as prices fall, leading to coefficient estimates of less than one on firm price in option grant value regressions. Also consistent with increased risk aversion and less diversification following stock price advances, we find that the link between price and option grant value is less for executives with a large ownership stake in the firm, relative to middle managers and executives with a small ownership share.

Incorporating risk aversion and diversification into our option valuation is beyond the scope of this paper, but regardless of valuation method, we find that as prices rise, executives receive a smaller number of grants relative to middle management, for whom the lack of diversification is less important.

\section{E. Other Determinants of Option Grants}

Our primary focus has been on how increases in firm value are shared with employees through increased compensation. There are clearly other factors that influence the granting of

\footnotetext{
${ }^{20}$ For an option granted at-the-money, the value of the option at the grant date can be decomposed into two parts, stock price at grant date and a Black-Scholes factor that depends on option life, volatility, and the dividend yield (but does not depend on stock price, since stock price equals exercise price). As long as the components of the BlackScholes factor do not change over time, the Black-Scholes factor will be absorbed in the fixed effect in our log specification. Thus, differences across firms in the life of the option, or even in risk aversion, will not affect our results, as long as these components do not vary over time in a way that is correlated with changes in stock price. This is why, for example, we obtain exactly the same point estimates when we assign options a life of ten years as we
} 
stock options, such as corporate governance, management skills, human resources policies, and firm-wide attitudes towards risk, which are likely picked up in the firm fixed effects because they do not change rapidly. Other factors, however, such as investment opportunities and financial constraints, which have been shown to be important cross-sectional determinants of the use of stock options (Core and Guay, 2001), may not be fully captured by our parsimonious fixed-effect specification because of their higher variability.

Table 13 presents estimates of stock option grant value per employee on stock price, free cash flow, and the market-to-book ratio. Free cash flow is net income plus depreciation expense less capital expenditures. We choose a linear specification because just over a quarter of the firms have negative free cash flow on average over 1996-99. The coefficients on the two price variables we use in the linear regressions, log price and market value per employee, each imply an elasticity of grant value with respect to price of .51 . This estimate is similar to the .45 pay for performance sensitivity estimated directly in the parsimonious log specification without any controls for financial constraints or the market-to-book ratio.

The coefficients on the market-to-book ratio and free cash flow are of independent interest. It is important to remember that both effects are identified by within-firm variation in these variables. A higher market-to-book ratio is associated with substantially higher stockbased compensation: An increase in the market-to-book ratio from 1.0 to 2.0 is associated with an increase from $\$ 1200$ to $\$ 1800$ in stock option grants per employee, suggesting firms grant more stock-based compensation when future investment opportunities have improved.

The coefficients on free cash flow are negative but small, and indicate that a $\$ 1$ decrease in free cash flow is associated with a $\$ .01$ increase in the value of stock option grants. As shown 
in columns (3) and (4), the negative relationship between option grants and free cash flow only holds for financially-strapped firms -- those with negative average free cash flow over the sample. This substitution to options for financially-strapped firms has the benefit of conserving cash, which might be very scarce, and an additional accounting benefit because earnings are not depressed further by options since they are not recorded as compensation expense. For firms that are not financially constrained, increased free cash flow does not translate into increased grants of stock options.

\section{F. Do Grants Affect Price?}

This paper presents estimates of how sensitive stock option grants are to past firm performance. One could turn this question around and ask whether the granting of stock options translates into higher stock prices (presumably through eliciting more effort and reducing the consumption of perquisites). ${ }^{\text {D }}$ In addition, companies may grant options ahead of the revealing good private information to benefit employees. Although we leave the question of whether stock option programs increase firm value to future research, we do present some preliminary results in Table 14. We regress stock price at the end of the year upon the value of options granted during the year and also upon the value of options granted during the previous year in a fixed-effects framework. We find some evidence that higher option grants during the year are associated with higher stock prices at the end of the year, however the estimated elasticity is only about .1 (a doubling of the value of option grants during the year is associated with a $10 \%$ higher stock price

\footnotetext{
${ }^{21}$ Empirical evidence on whether stock option grants boost performance and stock price is both limited and mixed. DeFusco, Johnson, and Zorn (1990) find a positive stock market reaction to the approval of an executive option plan. Anderson, Banker, and Ravindran (2000) and Ittner, Lambert and Larcker (2001) find evidence that the fraction of pay in option grants is positively correlated with same period stock returns, and that greater-than-expected option grants for mid-level employees lead to higher stock returns in the following year, respectively. In contrast, Aboody (1996) finds a negative relationship between the value of outstanding options and share price.
} 
at the end of the year). ${ }^{22}$ The elasticity of stock price with respect to option grant value is unchanged with the inclusion of long-term I/B/E/S earnings forecasts (see Table 14). ${ }^{2}$

This result is consistent with Yermack (1997) who finds that companies tend to make executive option grants shortly before the announcement of good news, such as earnings announcements, and the subsequent run-up in stock prices. This timing could help explain the correlation between grants and subsequent stock prices, at least in the short-term. However, we find no evidence of sustained improved performance as there is no relationship between grants made last year and stock prices at the end of the following year (specifications (3) and (4) of Table 14). Clearly the performance consequence of stock options is a topic that will generate much future research.

\section{Conclusion}

We have examined the sensitivity of employee stock option grants to firm performance for top executives and separately for other employees using a large sample of firms from Execucomp during 1996-99. Our regression results of stock option grant values on firm stock price suggest substantial pay-for-performance sensitivities for top executives and for employees below the senior ranks. However, counter to agency models that would predict lower sensitivities for employees whose actions have less effect on stock price, the pay-for-performance sensitivities for employees outside of top management is on average almost twice the size of that for top executives.

\footnotetext{
${ }^{22}$ Nearly all stock options are granted at the money. Therefore, if all options were granted at the end of the year, there would be a built in positive correlation between price at the end of the year and option grants during the year because the value of the option grant would contain the stock price at the end of the year.

${ }^{23}$ The elasticity of price to grant value is also robust to the inclusion of other financial controls such as earnings,
} 
We explore a number of hypotheses consistent with the agency framework to explain this difference. To some extent, the lower sensitivity of option grants appears to reflect that top executives have higher ownership stakes than middle management, but elasticities for top executives that have low ownership are still lower than those for middle management. In addition, firms offset price declines by granting more options to top executives to mitigate adverse incentives to take on greater risks or reduce effort when options are underwater, but do not do so for middle management whose actions have less effect. These results suggest that the asymmetric effect of price changes on incentives arising from options can explain some of the difference in pay-for-performance elasticities between top executives and middle management, but not the entire difference. Performance elasticities are equally disparate at new economy technology firms, where it might be assumed that middle management has relatively greater effect on firm value. We also find that stock option grants to both top executives and middle management are related to industry performance, reflecting greater demand for executives with skills to manage large organizations when industry stock prices rise. Moreover, this industry effect increases substantially with the size of the firm, consistent with Himmelberg and Hubbard's hypothesis that the supply of top executives with the ability to run large organizations is relatively inelastic.

We find that none of these factors can adequately explain the relatively higher pay-forperformance sensitivity for middle management. Thus, our results may be consistent with greater demand from middle management employees for options in periods of rising prices, which can be viewed as paying for the chance to become very wealthy. Such behavior has been documented in other studies of investor behavior: Benartzi (2001) shows that purchases of 
company stock in $401(\mathrm{k})$ plans increases with past returns, consistent with excessive extrapolation of returns, and Lambert and Larcker (2001) survey results show employees overestimate the value of their employee stock options, relative to Black-Scholes values, and that the overestimate is higher when previous returns have been higher.

Our results also have implications for the aggregate use of stock options. Our estimates suggest that much of the explosive growth in the use of employee stock options has been due to rising stock prices, at the firm and industry level. Using the coefficient on stock price from the baseline specification, we estimate that the change in stock prices can explain about two-thirds of the increase in the value of stock options granted by S\&P 1500 firms during 1996-99. These results imply that when stock prices fall, the willingness of middle management to accept options in lieu of cash compensation will diminish. Because the value of employee stock option grants is not recorded as a compensation expense under current accounting standards, as are cash wages, the reluctance of employees to accept options could result in higher expenses and lower reported profits when the stock market turns down. An interesting topic for future research would be to compare beliefs of expected stock returns held by mid-level employees with those held by upper management, and to examine how firms adjust compensation packages of cash and options.

The results also shed some light on critics' claims that the enormous gains realized by top executives during the raging bull market have been due to "luck" and, hence, in some sense undeserved. Our results provide some evidence that this may not be the case. For example, after controlling for industry performance, executives in firms that have performed better have received more compensation via options. Moreover, large industry performance gains could reflect tighter labor markets for a limited supply of top executives with the skills to manage large 
organizations. Our finding of a positive coefficient on industry performance that increases with assets is consistent with firms granting more employee stock options in response to heightened labor market pressures. 


\section{References}

Aboody, D., 1996, Market Valuation of Employee Stock Options, Journal of Accounting and Economics 22, 357-391.

Anderson, M., R. Banker, and S. Ravindran, 2000, Executive Compensation in the Information Technology Industry, Management Science 46, 530-547.

Baker, G and Hall, B, 1998, Understanding top management incentives: Firm size, risk and CEO effort, Harvard Business School.

Benartzi, S, 2001, Excessive extrapolation and the allocation of 401(k) accounts to company stock, Journal of Finance 56: 1747-64.

Bertrand, M and Mullainathan S, 2001, Are CEOS rewarded for luck? The ones without principals are, The Quarterly Journal of Economics, August, 901-931.

Carpenter, J., 1998, The exercise and valuation of executive stock options. Journal of Financial Economics 48, 127-158.

Carter, M. and Lynch, L., 2000, An examination of executive stock option repricing. Working paper. Columbia University and University of Virginia.

Core, J. and W. Guay, 1999, The use of equity grants to manage optimal equity incentive levels, Journal of Accounting and Economics 28, 151-184.

Core, J. and W. Guay, 2001, Stock option plans for non-executive employees, Journal of Financial Economics, forthcoming.

Core, J. and D. Larcker, 2000, Performance consequences of mandatory increases in CEO stock ownership. Working paper, The Wharton School.

DeFusco, R., R. Johnson, and T. Zorn, 1990, The Effect of Executive Stock Option Plans on Stockholders and Bondholders, Journal of Finance, 45, 617-627.

Fee, C. E., and C. Hadlock, 2001, Raids, rewards, and reputations in the market for CEO talent. Working paper, Michigan State University.

Garen, J.E., 1994, Executive compensation and principal-agent theory, Journal of Political Economy, CII, 1175-1199.

Grinblatt, M., Titman, S, and Wermers R, 1995, Momentum investment strategies, portfolio performance, and herding: A study of mutual fund behavior, American Economic Review, Vol. 85, No. 5, December, 1088-1105. 
Hall, B., 1998, The pay to performance incentives of executive stock options. NBER working paper 6674.

Hall, B. and J. Liebman, 1998, Are CEOs really paid like bureaucrats? The Quarterly Journal of Economics 113, 653-691.

Hall, B. and Murphy, K., 2000, Stock options for undiversified executives. Working paper.

Himmelberg, C. and Hubbard, G., 2000, Incentive pay and the market for CEOs: An analysis of pay-for-performance sensitivity. Working paper. Columbia University

Holmstrom, B and Milgrom, P, 1987, Aggregation and linearity in the provision of intertemporal incentives, Econometrica, LV, 303-328.

Holmstrom, B., 1979, Moral hazard and observability. Bell Journal of Economics, 74-91.

Huberman, G. 2001. Familiarity breeds investment, Review of Financial Studies 14(3): 659-680.

Huddart, S., and Lang, M., 1996, Employee stock option exercises; an empirical analysis, Journal of Accounting and Economics 21, 5-43.

Ittner, C., R. Lambert, and D. Larcker, 2001, The structure and performance consequences of equity grants to employees of new economy firms. Working paper. The Wharton School.

John Hancock Financial Services, 1999, The Defined Contribution Plan Survey.

Lambert, R. and D. Larcker, 2001, How employees value (often incorrectly) their stock options, http://knowledge.wharton.upenn.edu.

Liang, N. and Sharpe, S., 1999, Share repurchases and employee stock options and their implications for S\&P 500 share retirements and expected returns. FEDS Working paper 1999-59. Federal Reserve Board.

Matsunaga S., 1995, The effects of financial reporting costs on the use of employee stock options. The Accounting Review 70, 1-26.

Meulbroek, L., 2000, The efficiency of equity linked compensation: Understanding the full cost of awarding executive stock options. Working paper.

Murphy, K., 1999, Executive Compensation. In Ashenfelter, O., Card, D. (Eds.), Handbook of Labor Economics, Vol. 3B. North Holland, Amsterdam.

Oyer, P., 2000, Why do firms use incentives that have no incentive effects? Working paper. Stanford University. 
Vanguard Group, Expecting lower market returns in the near term, December 2001.

Weisbenner, S., 2000, Corporate share repurchases in the 1990s: What role do stock options play? FEDS Working paper 2000-29. Federal Reserve Board.

Yermack, D., 1995, Do corporations award CEO stock options effectively?, Journal of Financial Economics 39, 237-269.

Yermack, D., 1997, Good Timing: CEO Stock Option Awards and Company News Announcements, Journal of Finance 52, 449-476. 


\section{Table 1: Employee Stock Option Grants by S\&P 1500 Firms}

\begin{tabular}{|c|c|c|c|c|}
\hline \multicolumn{5}{|c|}{$\begin{array}{l}\text { Number of stock option grants } \\
\text { (percent of shares outstanding) }\end{array}$} \\
\hline & 1996 & 1997 & 1998 & 1999 \\
\hline All S\&P 1500 firms & 1.41 & 1.62 & 1.66 & 1.83 \\
\hline \multicolumn{5}{|l|}{ By firm size: } \\
\hline S\&P 500 & 1.30 & 1.47 & 1.49 & 1.68 \\
\hline S\&P small-cap \& mid-cap & 1.86 & 2.22 & 2.49 & 2.70 \\
\hline \multicolumn{5}{|l|}{ By industry: } \\
\hline Technology & 2.28 & 2.55 & 2.50 & 2.52 \\
\hline Non-Technology & 1.21 & 1.38 & 1.40 & 1.50 \\
\hline \multicolumn{5}{|l|}{ By employee type: } \\
\hline Top executives (total for top five) & .23 & .26 & .25 & .25 \\
\hline CEO only & .10 & .12 & .11 & .10 \\
\hline Middle management & 1.18 & 1.37 & 1.41 & 1.58 \\
\hline $\begin{array}{l}\text { Ratio of top executive option grants to } \\
\text { firm-wide grants }\end{array}$ & .17 & .17 & .15 & .14 \\
\hline Fraction of firms that grant options & .93 & .94 & .95 & .96 \\
\hline \multicolumn{5}{|c|}{ Value of stock option grants per employee (\$) } \\
\hline & 1996 & 1997 & 1998 & 1999 \\
\hline All S\&P 1500 firms & 1058 & 1475 & 1878 & 2508 \\
\hline \multicolumn{5}{|l|}{ By firm size: } \\
\hline S\&P 500 & 993 & 1440 & 1861 & 2681 \\
\hline S\&P small-cap \& mid-cap & 1199 & 1547 & 1911 & 2108 \\
\hline \multicolumn{5}{|l|}{ By industry: } \\
\hline Technology & 2290 & 3036 & 4063 & 5811 \\
\hline Non-Technology & 792 & 1116 & 1366 & 1667 \\
\hline \multicolumn{5}{|l|}{ By employee type: } \\
\hline Top executives (per executive) & 427,600 & 604,800 & 772,200 & $1,167,200$ \\
\hline CEO only & $1,109,900$ & $1,742,800$ & $2,006,600$ & $2,468,000$ \\
\hline Middle management & 879 & 1232 & 1589 & 2159 \\
\hline Top-executives cash salary and bonus & 557,400 & 578,900 & 615,700 & 725,700 \\
\hline CEO cash salary and bonus & $1,028,500$ & $1,070,200$ & $1,123,700$ & $1,300,600$ \\
\hline
\end{tabular}

Computations based on Execucomp database and various 10-Ks.

The number of grants as a percent of shares outstanding is weighted by the average of beginning and end of year market value across firms to compute the aggregate numbers. Grant values per employee are weighted by the number of employees across firms to compute the aggregate numbers. 


\section{Table 2:}

\section{Regression of Compensation per Employee on Firm Stock Price 1996-99, S\&P 1500 Firms}

(standard errors in parentheses)

\begin{tabular}{|c|c|c|c|c|c|}
\hline & $\begin{array}{l}\text { Stock Option } \\
\text { Grant Value: } \\
\text { All Employees }\end{array}$ & $\begin{array}{l}\text { Stock Option } \\
\text { Grant Value: } \\
\text { Top Executives }\end{array}$ & $\begin{array}{l}\text { Grant Value: } \\
\text { Middle } \\
\text { Management }\end{array}$ & $\begin{array}{c}\text { Cash Salary \& } \\
\text { Bonus 1996-99: } \\
\text { Top Executives }\end{array}$ & $\begin{array}{c}\text { Cash Salary \& } \\
\text { Bonus 1992-95: } \\
\text { Top Executives }\end{array}$ \\
\hline $\begin{array}{c}\log \text { (Stock } \\
\text { Price) }\end{array}$ & $\begin{array}{c}.45 \\
(.04)\end{array}$ & $\begin{array}{l}.29 \\
(.05)\end{array}$ & $\begin{array}{l}.53 \\
(.05)\end{array}$ & $\begin{array}{l}-.00 \\
(.01)\end{array}$ & $\begin{array}{l}.07 \\
(.01)\end{array}$ \\
\hline 1996 dummy & $\begin{array}{l}-.36 \\
(.04)\end{array}$ & $\begin{array}{l}.66 \\
(.04)\end{array}$ & $\begin{array}{l}-.32 \\
(.04)\end{array}$ & $\begin{array}{l}.25 \\
(.01)\end{array}$ & \\
\hline 1997 dummy & $\begin{array}{l}-.17 \\
(.04)\end{array}$ & $\begin{array}{l}-.41 \\
(.04)\end{array}$ & $\begin{array}{l}-.15 \\
(.04)\end{array}$ & $\begin{array}{l}-.17 \\
(.01)\end{array}$ & \\
\hline 1998 dummy & $\begin{array}{l}.08 \\
(.03)\end{array}$ & $\begin{array}{l}.21 \\
(.04)\end{array}$ & $\begin{array}{l}.08 \\
(.04)\end{array}$ & $\begin{array}{l}-.12 \\
(.01)\end{array}$ & \\
\hline \multicolumn{6}{|l|}{1999 omitted } \\
\hline 1992 dummy & & & & & $\begin{array}{l}-.15 \\
(.01)\end{array}$ \\
\hline 1993 dummy & & & & & $\begin{array}{l}-.11 \\
(.01) \\
\end{array}$ \\
\hline 1994 dummy & & & & & $\begin{array}{l}.05 \\
(.01)\end{array}$ \\
\hline \multicolumn{6}{|l|}{1995 omitted } \\
\hline within-firm $\mathrm{R}^{2}$ & .089 & .126 & .091 & .154 & .116 \\
\hline \# of observations & 5677 & 5128 & 5747 & 6365 & 5987 \\
\hline
\end{tabular}

Regressions are estimated over panel data from 1996-99 (1992-1995 for the last column) obtained from the Execucomp database and various 10-Ks. The basic regression specification is:

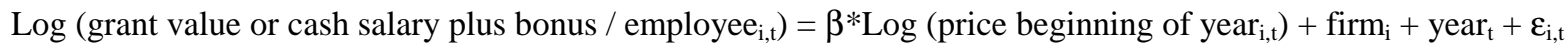


Table 3:

\section{Regression of Stock Option Grant Value per Employee on Firm Stock Price 1996-99,}

S\&P 1500 Firms

(standard errors in parentheses)

\begin{tabular}{|c|c|c|c|}
\hline & All Employees & Top Executives & $\begin{array}{c}\text { Middle } \\
\text { Management }\end{array}$ \\
\hline \multicolumn{4}{|c|}{ Regression coefficients on price when split sample by ownership share: } \\
\hline $\begin{array}{l}\text { Bottom quartile of ownership } \\
\text { (each top firm executive owns }<.15 \% \text { of firm on } \\
\text { average over 1997-98) }\end{array}$ & $\begin{array}{l}.53 \\
(.09)\end{array}$ & $\begin{array}{l}.41 \\
(.10)\end{array}$ & $\begin{array}{l}.63 \\
(.10)\end{array}$ \\
\hline $\begin{array}{l}\text { Middle two quartiles of ownership } \\
\text { (each top firm executive owns between .15-1.23\% of } \\
\text { firm on average over 1997-98) }\end{array}$ & $\begin{array}{l}.46 \\
(.06)\end{array}$ & $\begin{array}{l}.34 \\
(.07)\end{array}$ & $\begin{array}{l}.50 \\
(.06)\end{array}$ \\
\hline $\begin{array}{l}\text { Top quartile of ownership } \\
\text { (each top firm executive owns }>1.23 \% \text { of firm on } \\
\text { average over 1997-98) }\end{array}$ & $\begin{array}{l}.34 \\
(.08)\end{array}$ & $\begin{array}{l}.06 \\
(.09)\end{array}$ & $\begin{array}{l}.48 \\
(.08)\end{array}$ \\
\hline $\begin{array}{l}\text { p-value of test for equality between top quartile and } \\
\text { bottom quartile }\end{array}$ & .116 & .007 & .218 \\
\hline \multicolumn{4}{|c|}{ Regression coefficients on price when split sample by stock returns: } \\
\hline $\begin{array}{c}\text { Bottom quartile of returns } \\
\text { (average stock return }<6.9 \% \text { per year) }\end{array}$ & $\begin{array}{l}.35 \\
(.09) \\
\end{array}$ & $\begin{array}{c}.04 \\
(.10) \\
\end{array}$ & $\begin{array}{c}.42 \\
(.10) \\
\end{array}$ \\
\hline $\begin{array}{c}\text { Middle two quartiles of returns } \\
\text { (average stock return between } 6.9-42.7 \% \text { ) }\end{array}$ & $\begin{array}{l}.47 \\
(.07)\end{array}$ & $\begin{array}{l}0 \\
.30 \\
(.08)\end{array}$ & $\begin{array}{l}.54 \\
(.07)\end{array}$ \\
\hline $\begin{array}{l}\text { Top quartile of returns } \\
\text { (average stock return }>42.7 \% \text { per year) }\end{array}$ & $\begin{array}{l}.50 \\
(.07) \\
\end{array}$ & $\begin{array}{c}.46 \\
(.08) \\
\end{array}$ & $\begin{array}{l}.59 \\
(.07) \\
\end{array}$ \\
\hline $\begin{array}{l}\text { p-value of test for equality between top quartile and } \\
\text { bottom quartile }\end{array}$ & .200 & .001 & .160 \\
\hline
\end{tabular}

Regressions estimated over all employees have 5677 observations, middle management regressions have 5647 observations, and top executive regressions have 5128 observations (except for the cash-based salary regression, which has 5833 observations). Regressions are estimated over panel data from 1996-99 obtained from the Execucomp database and various $10-\mathrm{Ks}$. The basic regression specification is:

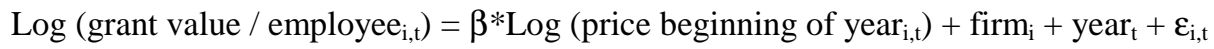

The sample is first divided into three groups by average ownership share over 1997-98 (top panel). We estimate a second regression where the sample is instead divided into three groups by average stock returns over 1996-99 (bottom panel). The three groups are the bottom quartile, middle two quartiles, and top quartile of either average ownership share or average stock returns. The coefficient on log price is then allowed to vary across the three groups.

See text for further details. 
Table 4: Industry Prices

(all industry prices normalized to 100 at end of 1995)

\begin{tabular}{|l|c|c|}
\hline & Value end of 1997 & Value end of 1999 \\
\hline Mining & 100.8 & 143.0 \\
\hline Oil \& Gas & 178.5 & 116.2 \\
\hline Construction & 119.8 & 140.7 \\
\hline Food & 162.3 & 162.4 \\
\hline Basic Materials & 141.5 & 225.4 \\
\hline Biotech / Medical & 166.4 & 167.0 \\
\hline Manufacturing & 147.4 & 145.5 \\
\hline Transportation & 147.9 & 275.7 \\
\hline Telecom & 146.9 & 123.1 \\
\hline Utilities & 135.6 & 219.9 \\
\hline Retail / Wholesale Trade & 159.4 & 218.2 \\
\hline Financial & 195.0 & 420.5 \\
\hline Technology & 174.1 & 157.7 \\
\hline Other & 131.7 & \\
\hline
\end{tabular}

Returns (weighted by market value) are calculated for the fourteen industry groups using the entire sample of Execucomp firms (S\&P 1500). The returns are then used to construct a time series of industry prices. 


\section{Table 5: Regression of Stock Option Grant Values upon both Own and Industry Prices}

(standard errors in parentheses)

\begin{tabular}{|c|c|c|c|}
\hline & All Employees & Top Executives & $\begin{array}{c}\text { Middle } \\
\text { Management }\end{array}$ \\
\hline \multicolumn{4}{|c|}{ Regression coefficients for all S\&P 1500 firms } \\
\hline Firm Price & $\begin{array}{l}.43 \\
(.04)\end{array}$ & $\begin{array}{l}.27 \\
(.05)\end{array}$ & $\begin{array}{l}.52 \\
(.05)\end{array}$ \\
\hline Industry Price & $\begin{array}{l}.26 \\
(.13) \\
\end{array}$ & $\begin{array}{c}.43 \\
(.14) \\
\end{array}$ & $\begin{array}{c}.26 \\
(.13) \\
\end{array}$ \\
\hline \multicolumn{4}{|c|}{$\begin{array}{l}\text { Regression coefficients for all S\&P } 1500 \text { firms } \\
\text { (allow coefficient on Industry Price to vary with size of firms) }\end{array}$} \\
\hline Firm Price & $\begin{array}{c}.41 \\
(.05) \\
\end{array}$ & $\begin{array}{l}.24 \\
(.05) \\
\end{array}$ & $\begin{array}{c}.48 \\
(.05) \\
\end{array}$ \\
\hline \multicolumn{4}{|l|}{ Industry Price Variables } \\
\hline $\begin{array}{l}\text { Bottom quartile of size } \\
\text { (Average book value of firm's assets }<\$ 357 \text { million } \\
\text { over 1997-98) }\end{array}$ & $\begin{array}{l}-.02 \\
(.15)\end{array}$ & $\begin{array}{l}.15 \\
(.17)\end{array}$ & $\begin{array}{l}-.07 \\
(.16)\end{array}$ \\
\hline $\begin{array}{l}\text { Middle two quartiles of size } \\
\text { (Average book value of firm's assets between \$357- } \\
3700 \text { million over 1997-98) }\end{array}$ & $\begin{array}{l}.29 \\
(.14)\end{array}$ & $\begin{array}{l}.47 \\
(.15)\end{array}$ & $\begin{array}{l}.29 \\
(.14)\end{array}$ \\
\hline $\begin{array}{l}\quad \text { Top quartile of size } \\
\text { (Average book value of firm's assets }>\$ 3700 \\
\text { million over 1997-98) }\end{array}$ & $\begin{array}{l}.48 \\
(.15)\end{array}$ & $\begin{array}{l}.59 \\
(.17)\end{array}$ & $\begin{array}{l}.55 \\
(.16)\end{array}$ \\
\hline $\begin{array}{l}\text { p-value of test for equality between top quartile and } \\
\text { bottom quartile }\end{array}$ & .001 & .007 & .000 \\
\hline
\end{tabular}

Regressions estimated over all employees have 5677 observations, middle management regressions have 5647 observations, and top executive regressions have 5128 observations. Regressions are estimated over panel data from 1996-99 obtained from the Execucomp database and various 10-Ks. The basic regression specification is:

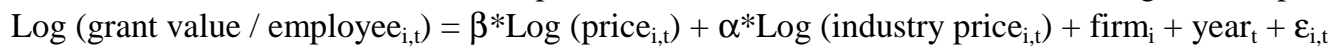

Prices are measured at the beginning of the year. Fourteen industry indices (prices) are constructed over the sample period. The industry groupings are mining, oil and gas, construction, food, basic materials, biotech/medical, manufacturing, transportation, telecom, utilities, retail/wholesale trade, financial, technology, and other.

In the bottom panel, the industry price variable is divided into three groups by firm size (book value of assets averaged over 1997-98). The coefficient on log industry price is then allowed to vary across the three firm size groups.

See text for further details. 


\section{Table 6:}

\section{Regression of Stock Option Grant Value with Interactions 1996-99}

(standard errors in parentheses)

\begin{tabular}{|c|c|c|c|}
\hline & All Employees & Top Executives & $\begin{array}{c}\text { Middle } \\
\text { Management }\end{array}$ \\
\hline \multicolumn{4}{|c|}{ Own Price Coefficients } \\
\hline Coefficient & $\begin{array}{c}.44 \\
(.08) \\
\end{array}$ & $\begin{array}{l}.31 \\
(.09)\end{array}$ & $\begin{array}{l}.47 \\
(.09)\end{array}$ \\
\hline Interaction with low executive share ownership & $\begin{array}{l}.02 \\
(.11)\end{array}$ & $\begin{array}{c}.05 \\
(.12)\end{array}$ & $\begin{array}{c}.06 \\
(.11)\end{array}$ \\
\hline Interaction with high executive share ownership & $\begin{array}{l}-.10 \\
(.10)\end{array}$ & $\begin{array}{l}-.32 \\
(.11)\end{array}$ & $\begin{array}{l}-.00 \\
(.10)\end{array}$ \\
\hline Interaction with low stock return & $\begin{array}{l}-.12 \\
(.12)\end{array}$ & $\begin{array}{l}-.27 \\
(.13)\end{array}$ & $\begin{array}{ll}-.11 \\
(.13)\end{array}$ \\
\hline Interaction with high stock return & $\begin{array}{l}.06 \\
(.09)\end{array}$ & $\begin{array}{c}.24 \\
(.10)\end{array}$ & $\begin{array}{l}.08 \\
(.10)\end{array}$ \\
\hline $\begin{array}{l}\text { p-value of test for equality between high and low } \\
\text { executive ownership }\end{array}$ & .334 & .007 & 635 \\
\hline $\begin{array}{l}\text { p-value of test for equality between high and low } \\
\text { stock returns }\end{array}$ & .144 & .000 & .129 \\
\hline \multicolumn{4}{|c|}{ Industry Price Coefficients } \\
\hline Coefficient & $\begin{array}{l}.28 \\
(.14)\end{array}$ & $\begin{array}{c}.44 \\
(.15)\end{array}$ & $\begin{array}{l}.28 \\
(.14)\end{array}$ \\
\hline Interaction with low assets & $\begin{array}{l}-.31 \\
(.13)\end{array}$ & $\begin{array}{l}-.36 \\
(.15)\end{array}$ & $\begin{array}{l}-.37 \\
(.14)\end{array}$ \\
\hline Interaction with high assets & $\begin{array}{l}.17 \\
(.12)\end{array}$ & $\begin{array}{l}.06 \\
(.13) \\
\end{array}$ & $\begin{array}{l}.25 \\
(.13)\end{array}$ \\
\hline $\begin{array}{l}\text { p-value of test for equality between high and low } \\
\text { assets }\end{array}$ & .002 & .012 & .000 \\
\hline within-firm $\mathrm{R}^{2}$ & .092 & .136 & .096 \\
\hline
\end{tabular}

Regressions estimated over all employees have 5677 observations, middle management regressions have 5647 observations, and top executive regressions have 5128 observations. Regressions are estimated over panel data from 1996-99 obtained from the Execucomp database and various 10-Ks. The basic regression specification is:

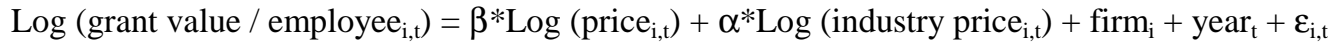

Prices are measured at the beginning of the year. Fourteen industry indices (prices) are constructed over the sample period. The industry groupings are mining, oil and gas, construction, food, basic materials, biotech/medical, manufacturing, transportation, telecom, utilities, retail/wholesale trade, financial, technology, and other.

The coefficient on log price is interacted with whether the average executive ownership share over 1997-98 is in the bottom or top quartile and whether the average stock return over the sample is in the bottom or top quartile of the sample firms. The coefficient on log industry price is interacted with whether firm size (book value of assets averaged over 1997-98) is in the bottom or top quartile of the sample firms.

See text for further details. 


\section{Table 7:}

\section{Regression of Number of Stock Option Grants per Employee on Firm Stock Price 1996-99}

\section{(standard errors in parentheses)}

\begin{tabular}{|c|c|c|c|}
\hline & All Employees & Top Executives & $\begin{array}{c}\text { Middle } \\
\text { Management }\end{array}$ \\
\hline Firm Price & $\begin{array}{l}.23 \\
(.04) \\
\end{array}$ & $\begin{array}{l}-.39 \\
(.05) \\
\end{array}$ & $\begin{array}{l}-.14 \\
(.05) \\
\end{array}$ \\
\hline \multicolumn{4}{|c|}{ Regression coefficients when add industry price to the specification } \\
\hline Firm Price & $\begin{array}{l}-.23 \\
(.04) \\
\end{array}$ & $\begin{array}{l}-.40 \\
(.05)\end{array}$ & $\begin{array}{l}-.15 \\
(.05)\end{array}$ \\
\hline Industry Price & $\begin{array}{c}.08 \\
(.12) \\
\end{array}$ & $\begin{array}{c}.26 \\
(.13) \\
\end{array}$ & $\begin{array}{c}.08 \\
(.13) \\
\end{array}$ \\
\hline
\end{tabular}

Regressions estimated over all employees have 5677 observations, middle management regressions have 5647 observations, and top executive regressions have 5128 observations. Regressions are estimated over panel data from 1996-99 obtained from the Execucomp database and various 10-Ks. The basic regression specification is: $\log \left(\right.$ number of grants $/$ employee $\left._{i, t}\right)=\beta * \log \left(\right.$ price beginning of year $\left._{i, t}\right)+$ firm $_{i}+$ year $_{t}+\varepsilon_{i, t}$

Prices are measured at the beginning of the year. Fourteen industry indices (prices) are constructed over the sample period. The industry groupings are mining, oil and gas, construction, food, basic materials, biotech/medical, manufacturing, transportation, telecom, utilities, retail/wholesale trade, financial, technology, and other. 


\section{Table 8: Frequency Executive of a Firm is Reported in Proxy Statement 1996-99}

(number of times an individual is a "top executive")

\begin{tabular}{|c|c|c|c|}
\hline $\begin{array}{c}\text { Number of years } \\
\text { firm is in sample }\end{array}$ & $\begin{array}{c}\text { Mean number of times } \\
\text { executive is mentioned } \\
\text { in proxy statement }\end{array}$ & $\begin{array}{c}\text { Median number of times } \\
\text { executive is mentioned } \\
\text { in proxy statement }\end{array}$ & $\begin{array}{c}\text { \% of executives who are } \\
\text { included in proxy } \\
\text { statement every year }\end{array}$ \\
\hline 1 & 1 & 1 & $100 \%$ \\
\hline 2 & 1.8 & 2 & 79 \\
\hline 3 & 2.5 & 3 & 65 \\
\hline 4 & 3.0 & 3 & 49 \\
\hline
\end{tabular}

Source: Execucomp. There are a total of 2143 different companies from 1996-99: 146 appear in the sample one year, 150 appear two years, 359 appear three years, and 1488 appear all four years.

Table 9: Regression of Stock Option Grant Value per Employee for Low Turnover Firms

(standard errors in parentheses)

\begin{tabular}{|c|c|c|c|}
\hline & All Employees & Top Executives & $\begin{array}{c}\text { Middle } \\
\text { Management }\end{array}$ \\
\hline \multicolumn{4}{|c|}{ Regression coefficients for all S\&P 1500 firms } \\
\hline Firm Price & $\begin{array}{c}.42 \\
(.10)\end{array}$ & $\begin{array}{r}.36 \\
(.11) \\
\end{array}$ & $\begin{array}{r}.53 \\
(.11) \\
\end{array}$ \\
\hline \multicolumn{4}{|c|}{$\begin{array}{l}\text { Regression coefficients for all S\&P } 1500 \text { firms } \\
\text { (add Industry Price to specification) }\end{array}$} \\
\hline Firm Price & $\begin{array}{c}.39 \\
(.11)\end{array}$ & $\begin{array}{c}.32 \\
(.11)\end{array}$ & $\begin{array}{c}.51 \\
(.11)\end{array}$ \\
\hline Industry Price & $\begin{array}{c}.48 \\
(.28)\end{array}$ & $\begin{array}{l}.57 \\
(.30)\end{array}$ & $\begin{array}{l}.29 \\
(.31)\end{array}$ \\
\hline
\end{tabular}

To be included in the sample, the firm must have low turnover among its top executives. For firms that are in the sample two years, executives covered by the proxy statement must be reported in the proxy statement both years. For firms that are in the sample three (four) years, executives covered by the proxy statement must be reported in the proxy statement at least three (four) years. The low turnover sample has 1359 firm-year observations.

Regressions are estimated over panel data from 1996-99 obtained from the Execucomp database and various 10-Ks. The basic regression specification is:

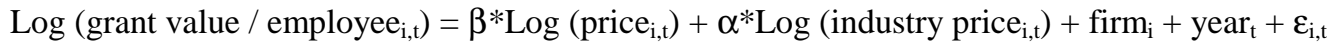

Prices are measured at the beginning of the year. Fourteen industry indices (prices) are constructed over the sample period. The industry groupings are mining, oil and gas, construction, food, basic materials, biotech/medical, manufacturing, transportation, telecom, utilities, retail/wholesale trade, financial, technology, and other.

See text for further details. 
Table 10: Stock Option Exercises per Employee for S\&P 500 (1996-99)

\begin{tabular}{|c|c|c|}
\hline & $\begin{array}{c}\text { Value of shares exercised as a } \\
\text { percent of firm market value }\end{array}$ & $\begin{array}{c}\text { Gain per employee from option } \\
\text { exercises }\end{array}$ \\
\hline 1996 & 1.0 & $\$ 1600$ \\
\hline 1997 & 1.1 & 2600 \\
\hline 1998 & 1.2 & 3600 \\
\hline 1999 & 1.3 & 4800 \\
\hline
\end{tabular}

Source: $10-\mathrm{K}$ statements.

Data were collected for the members of the S\&P 500 at the end of 1998 over the period 1996-99 (467 firms in existence with data on options over the entire period). The gain per employee is calculated assuming options are exercised at the firm's year-end price. 


\section{Table 11:}

\section{Regression of Stock Option Grant Value per Employee on Gains from Option Exercises}

(standard errors in parentheses)

\begin{tabular}{|c|c|}
\hline & All Employees - S\&P 500 firms \\
\hline \multicolumn{2}{|c|}{$\begin{array}{c}\text { Regression coefficients } \\
\text { Dependent Variable }=\text { Log (Grant Value / Employee })\end{array}$} \\
\hline Log (Firm Price) & $\begin{array}{r}.45 \\
(.10) \\
\end{array}$ \\
\hline Log (Gains from Option Exercises / Employee) & $\begin{array}{l}.11 \\
(.02) \\
\end{array}$ \\
\hline \multicolumn{2}{|c|}{$\begin{array}{c}\text { Regression coefficients } \\
\text { Dependent Variable = Grant Value / Employee }\end{array}$} \\
\hline $\begin{array}{l}\text { Log (Firm Price) } \\
\text { implied elasticity of grant value with respect } \\
\text { to price (evaluated at sample means) }\end{array}$ & $\begin{array}{r}1436 \\
(470) \\
.42 \\
\end{array}$ \\
\hline Gains from Option Exercises / Employee & $\begin{array}{c}.07 \\
(.01)\end{array}$ \\
\hline
\end{tabular}

Data were collected on firm-wide option exercises for the members of the S\&P 500 at the end of 1998 over the period 1996-99 (467 firms in existence with data on options over the entire period). The gain per employee is calculated assuming options are exercised at the firm's year-end price. The top panel displays regression results for the S\&P 500 for all employees when grant value and exercise gains are in logs. Of the original 1868 firm-year observations, 1317 could be merged into the Execucomp data and included in the log-log regression (the rest were lost to zero grants, insufficient data to calculate Black-Scholes value, or zero estimated gains from exercises). The bottom panel displays regression results for the S\&P 500 when grant value and exercise gains are expressed in levels (1478 observations included in this regression).

The basic regression specification in the top panel is:

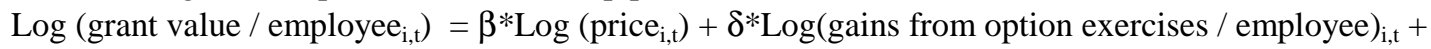

$$
\text { firm }_{\mathrm{i}}+\text { year }_{\mathrm{t}}+\varepsilon_{\mathrm{i}, \mathrm{t}}
$$

The basic regression specification in the second panel is:

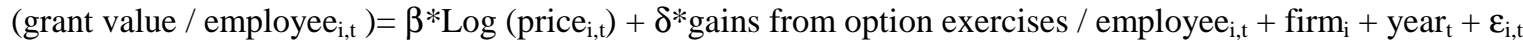

Prices are measured at the beginning of the year. Fourteen industry indices (prices) are constructed over the sample period. The industry groupings are mining, oil and gas, construction, food, basic materials, biotech/medical, manufacturing, transportation, telecom, utilities, retail/wholesale trade, financial, technology, and other. See text for further details. 


\section{Table 12:}

\section{Regression of Stock Option Grant Values on Own Price for Tech and Non-tech Firms}

(standard errors in parentheses)

\begin{tabular}{|c|c|c|c|}
\hline & All Employees & Top Executives & $\begin{array}{c}\text { Middle } \\
\text { Management }\end{array}$ \\
\hline Regression coefficient on Firm Price for all S\&P 1500 firms (separate regressions for tech and non-tech) \\
\hline Tech firms & .47 & .29 & .55 \\
& $(.07)$ & $(.09)$ & $(.07)$ \\
\hline Non-tech firms & .44 & .29 & .52 \\
& $(.05)$ & $(.06)$ & $(.06)$ \\
\hline
\end{tabular}

There are 1249 firm-year observations for technology firms and 4428 firm-year observations for non-technology firms. Regressions are estimated over panel data from 1996-99 obtained from the Execucomp database and various $10-$ Ks. The basic regression specification is:

$\log \left(\right.$ grant value $/$ employee $\left._{\mathrm{i}, t}\right)=\beta * \log \left(\right.$ price $\left._{\mathrm{i}, \mathrm{t}}\right)+$ firm $_{\mathrm{i}}+$ year $_{\mathrm{t}}+\varepsilon_{\mathrm{i}, \mathrm{t}}$ 


\section{Table 13: Other Determinants of Option Grants per Employee}

\section{(standard error in parentheses)}

\begin{tabular}{|c|c|c|c|c|}
\hline & (1) & (2) & (3) & (4) \\
\hline$\overline{\log \text { (Price) }}$ & $\begin{array}{l}2469 \\
(622)\end{array}$ & & $\begin{array}{l}2273 \\
(625)\end{array}$ & \\
\hline Market Value per employee & & $\begin{array}{c}.0052 \\
(.0005)\end{array}$ & & $\begin{array}{c}.0051 \\
(.0005)\end{array}$ \\
\hline Market-to-Book & $\begin{array}{l}1829 \\
(305) \\
\end{array}$ & $\begin{array}{l}1217 \\
(255) \\
\end{array}$ & $\begin{array}{l}1854 \\
(305) \\
\end{array}$ & $\begin{array}{l}1225 \\
(255) \\
\end{array}$ \\
\hline Free cash flow per employee & $\begin{array}{l}-.013 \\
(.001)\end{array}$ & $\begin{array}{l}-.007 \\
(.001)\end{array}$ & & \\
\hline $\begin{array}{l}\text { Free cash flow per employee } \\
\text { (firms with average FCF > 0) }\end{array}$ & & & $\begin{array}{r}.015 \\
(.011) \\
\end{array}$ & $\begin{array}{c}.004 \\
(.011) \\
\end{array}$ \\
\hline $\begin{array}{l}\text { Free cash flow per employee } \\
\text { (firms with average FCF < 0) }\end{array}$ & & & $\begin{array}{l}-.013 \\
(.001) \\
\end{array}$ & $\begin{array}{l}-.007 \\
(.001)\end{array}$ \\
\hline within-firm $\mathrm{R}^{2}$ & .097 & .136 & .099 & .136 \\
\hline $\begin{array}{l}\text { implied elasticity of grant value } \\
\text { with respect to price } \\
\text { (evaluated at sample means) }\end{array}$ & .51 & .51 & .47 & .50 \\
\hline
\end{tabular}

Regressions are estimated over panel data from 1996-99 obtained from the Execucomp database and various 10-Ks. The basic regression specification is estimated for all employees:

grant value / employe $e_{i, t}=\beta * \log \left(\right.$ price $\left._{i, t}\right)+\alpha^{*}$ market-to-book $_{\mathrm{i}, \mathrm{t}}+\delta^{*}$ free cash flow $_{\mathrm{i}, \mathrm{t}-1}+$ firm $_{\mathrm{i}}+$ year $_{\mathrm{t}}+\varepsilon_{\mathrm{i}, \mathrm{t}}$ grant value / employee ${ }_{i, t}=\beta *$ market value $_{i, t}+\alpha^{*}$ market-to-book $_{\mathrm{i}, \mathrm{t}}+\delta^{*}$ free cash flow $_{\mathrm{i}, \mathrm{t}-1}+$ firm $_{\mathrm{i}}+$ year $_{\mathrm{t}}+\varepsilon_{\mathrm{i}, \mathrm{t}}$

Price, firm market value, and the market-to-book ratio are measured at the beginning of the year. Free cash flow is net income plus depreciation less capital expenditures. Free cash flow and firm market value are expressed in dollars per employee.

Specifications (3) and (4) allow the coefficient on free cash flow to be different for firms with average free cash flow per employee greater than and less than zero over the sample.

See text for further details. 


\section{Table 14: Do Option Grants Lead to Higher Prices? Regression of Stock Price on Option Grants}

(standard error in parentheses)

\begin{tabular}{|c|c|c|c|c|}
\hline & $(1)$ & $(2)$ & $(3)$ & $(4)$ \\
\hline Log (grant value / employee) & .10 & .09 & & \\
& $(.01)$ & $(.01)$ & .01 & .01 \\
& & & $(.01)$ & $(.01)$ \\
\hline Log (grant value / employee) $\mathrm{t}-1$ & & & & $(.29)$ \\
\hline I/B/E/S long-term earnings growth & & 3.75 & $.23)$ & .140 \\
\hline within-firm R ${ }^{2}$ & .087 & .175 & .055 & \\
\hline
\end{tabular}

Regressions are estimated over panel data from 1996-99 obtained from the Execucomp database and various 10-Ks. The basic regression specifications estimated for all employees:

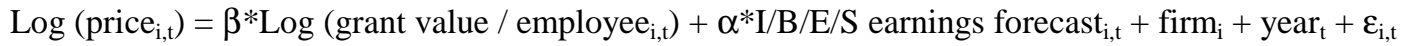

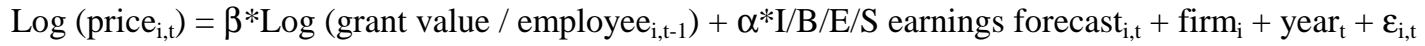

Price, and the long-term I/B/E/S earnings forecast are measured at the end of the current fiscal year. The grant value per employee reflects grants made during the current fiscal year. There are 5724 firm-year observations, inclusion of the I/B/E/S long-term earnings forecast reduces the sample size to 5176 .

Specifications (3) and (4) relate stock prices at the end of the current year to option granted during the previous fiscal year, rather than the current year as in specifications (1) and (2).

See text for further details. 